\title{
A palavra em estado de ver
}

\author{
Otávio Henrique Meloni \\ (Universidade Federal Fluminense)
}

\section{RESUMO}

A poesia de João Maimona se apresenta como um diferencial no universo poético da Angola recente. São muitos os motivos que nos fazem pensar desta maneira, porém, neste texto, pretendemos analisar as relações estabelecidas pelo poeta com as artes plásticas, notoriamente em seu livro Lugar e origem da beleza, de 2003. Dessa forma, iremos observar de que maneira o poeta traz para seu fazer literário técnicas e referências de outras artes, neste caso em específico, a pintura.

PALAVRAS-CHAVE: poesia angolana, João Maimona, artes plásticas

\section{ABSTRACT}

The poetry of João Maimona presents itself as a differential in Angola's recent poetic universe. There are many reasons that make us think that way, but in this text, we intend to analyze the relationships established by the poet with the visual arts, notably in his book Lugare origem da beleza. Thus, we observe how the poet brings to his literacy techniques and references to other arts, in this case in particular, painting.

KEYWORDS: Angolan poetry, João Maimona, visual arts 
Como é difícil encontrar a palavra que te diga. Já não se pode inventar a esmo, nem mesmo dizer igual a tantos outros. Tu tens um nome que talvez não seja condizente com a tua forma, ou que talvez não expresse metade do teu sabor, das tuas curvas. Cansei-me de perder o sono, de cabeça vazia, debruçado sobre uma superfície infértil de ideias e resultados. Mas, e se essa letra se tornasse traço? E se essa voz aqui escondida se transformasse em cor? E se toda a folha fosse tela cheia, palavra por palavra, a desenhar uma figura nova a que chamarei de poema? O sono volta e adormeço lendo minha memória em quadros e a eles acrescentando gritos de cor, janelas de possibilidades. Acredito no teu rosto desenhado em letras, regressando em uma dessas insônias que me assolam. Acredito em tuas mãos, em tons pastéis, a me conduzir pela vida inteira, em vias de regresso à origem da beleza. Tudo o que escrevo é imagem. Tudo o que desenho é poema.

Não é de hoje que as linguagens visual e verbal se encontram para criar e recriar sentidos. Vivemos em um mundo planejado e constantemente repensado a partir das imagens. O que, há alguns séculos, era privilégio apenas da pintura e das gravuras ganhou novos artifícios para registrar e transpor imagens naturais e humanas a um status de eterno. Assim vieram a fotografia e o cinema, respectivamente. Ambos já se encontram na era digital, em que as imagens, antes de difícil captura, se tornam descartáveis pela facilidade que se tem de eleger o melhor ângulo ou enquadramento.

Porém, o que buscamos é uma outra maneira de ver e perceber as imagens, não apenas como cópia fiel do que se vê, mas como interpretação e tradução das diversas apreensões de mundo a que estamos suscetíveis através das artes. Para isso, convocamos o brasileiro João Guimarães Rosa e seu belo trecho de "Campo Geral":

Miguilim olhou. Nem não podia acreditar! Tudo era uma claridade, tudo novo e lindo e diferente, as coisas, as árvores, as caras das pessôas. Via os grãozinhos de areia, a pele da terra, as pedrinhas menores, as formiguinhas passeando no chão de um distância. E tonteava. Aqui, ali, meu Deus, tanta coisa, tudo... O senhor tinha retirado dele os óculos, e Miguilim ainda apontava, falava, contava tudo como era, como tinha visto. Mãe estava assim assustada; mas o senhor dizia que aquilo era do modo mesmo, só que Miguilim também carecia de usar óculos (...) O doutor entendeu e achou graça. Tirou os óculos, pôs na cara de Miguilim. E Miguilim olhou para todos, com tanta força. Saiu lá fora. Olhou os matos escuros de cima do morro, aqui em casa, a cerca de feijão-bravo e são-caetano; o céu, o curral, o quintal; os olhos redondos e os vidros altos da manhã. Olhou mais longe, o gado pastando perto do brejo, florido de são-josés, como um algodão. O verde dos buritis, na primeira vereda. O Mutum era bonito! Agora ele sabia. (ROSA, 2001, p. 149-152) 
Através do menino Miguilim e de sua estória, conhecemos uma constituição espacial que impressiona os leitores. Guimarães tece, durante toda a novela, uma sequência de descrições do Mutum que vai formando, na mente do leitor, uma perspectiva visual do ambiente no qual vive e cresce aquele menino com sua família. Logo no início do texto, ele retorna de uma pequena viagem, dizendo que as pessoas de fora acham o Mutum um lugar bonito. Ele se impressiona e resolve entregar essa notícia para mãe como se fora um presente. E ela, ressentida com a vida no lugar, responde com um lamento. A astúcia narrativa do autor de Grande sertão: veredas prossegue durante toda a estória, enquanto vai pincelando pequenas respostas ou agravantes dúvidas sobre a real imagem do Mutum. Até que, nas últimas páginas, surge a revelação que não esperávamos. Miguilim, por quem "víamos" quase todas as cenas, tinha um acentuado problema de visão e enxergava tudo embaçado, tremido. Ao receber os óculos do doutor, o fenômeno que acontece ao personagem ultrapassa a narrativa e alcança o leitor. Trata-se da elucidação das imagens e da capacidade de se construírem as próprias interpretações das mesmas. Com os óculos, Miguilim entra em um novo mundo e redescobre coisas que só conhecia de nome ou por uma visão "incompleta", se assim podemos chamá-la. A alegria, ao redescobrir o mundo em que vivia e nem podia imaginar, faz com que o menino exclame que o "Mutum era um lugar bonito" e que agora ele podia dizer isso.

Chamar Miguilim para iniciar nossas reflexões sobre a relação das palavras com as imagens é entender que o olhar é a ferramenta fundamental para compreendermos tal processo. É considerar que é através do olhar de quem vê, escreve, pinta ou fotografa que surgem as representações, posteriormente recriadas por quem lê, contempla ou analisa tais reproduções. Em seu poema "3 de maio" Oswald de Andrade nos revela: "aprendi com meu filho de dez anos/ que a poesia é a descoberta/ das coisas que nunca vi." (ANDRADE, 1990). Assim, a essência poética de criar e revelar imagens, através de palavras, recebe a chancela de descoberta de mundo(s) através do olhar. Se pensarmos um pouco mais na obra de Oswald, principalmente em seus dois romancesmontagem ${ }^{1}$, logo perceberemos a importância que a linguagem fotográfica assume na constituição de seu universo literário e como as "descobertas" são feitas e reveladas pelo olhar e pela constante conjugação de imagens.

O grande artifício oferecido pela linguagem verbal aos que dela fazem uso para instaurar e conceber, na escrita, as imagens apreendidas pelo olhar e (re)criadas pela imaginação é a metáfora. O papel da metáfora no universo literário acaba estendendo-se e ultrapassando os limites dados por alguns livros didáticos, pois ela ultrapassa a definição de significar apenas uma comparação implícita e passa a ser o fio condutor de um processo de ressignificação vocabular, espacial e visual. Dessa maneira, o escritor não apenas propõe uma nova roupagem para uma já existente apreensão do real, mas cria uma nova forma de expressão, um novo "lugar" semântico e vocabular, como nos diz Paul Ricoeur:

O criador de metáforas é esse artesão com habilidade verbal o qual, a partir de um enunciado inconsistente para uma interpretação literal, extrai um enunciado 
significativo para uma nova interpretação que merece ser chamada metafórica por gerar a metáfora não apenas como um desvio mas por ser também aceitável. Em outras palavras, o significado metafórico não consiste meramente em um choque semântico mas em um novo significado predicativo que surge a partir do colapso do significado literal, isto é, do colapso do significado que se obtém se confiarmos apenas nos valores lexicais usuais ou comuns de nossas palavras. A metáfora não é o enigma, mas a solução do enigma. (RICOEUR, 1992, p. 148)

O colapso literal proposto por Ricoeur é o que encontramos na poesia de João Maimona quando falamos de seu processo de metaforização inusitado ou ainda da construção de campos semânticos tipicamente paradoxais. Por isso, a intervenção do ensaísta para comprovar que a gmetáfora é a solução do enigma h. Isto é, não basta olharmos para ela como segmento sintático ou morfológico. A metáfora estabelece uma imagem que só funciona textualmente se é compreendida e apreendida por inteiro. E, como já dito por Octavio Paz: "O sentido da imagem é a própria imagem. (...) a imagem explica-se a si mesma. Nada, exceto ela, pode dizer o que quer dizer. Sentido e imagem são a mesma coisa." (PAZ, 1982, p. 133). Assim, se tentamos "desvendar" as intenções de um poeta ou de um romancista ao criar esta ou aquela metáfora, só o podemos fazer através de uma visão crítica que se proponha partir da imagem criada, e não pelo desmembramento vocabular e/ou sintático da sentença que constitui a metáfora.

Tais considerações são de extrema relevância para pensarmos este processo de construção e referenciação imagética dentro da relação interartes, neste caso específico, entre literatura e pintura. A cena rosiana de Miguilim, reencontrando e descobrindo o mundo que o cercava, poderia muito bem ser uma tela, ou uma seqüência de gravuras. Assim como a revelação de Oswald sobre o que é a poesia para ele nos mostra que a construção do olhar, das telas do real e do imaginado são a base da composição poética. Chegamos, então, ao livro Lugar e origem da beleza, de João Maiomona, publicado de 2003. Escolhemos esta obra, pois julgamos ser aqui o lugar em que os vértices da memória, da paisagem do texto e do sujeito lírico se encontram para promover uma celebração da palavra poética. Para elevá-la ao seu ponto extremo de significação e beleza. Para fazer com que a palavra seja não só capaz de dizer, mas também de estampar sentidos. Nele, alguns poemas ou sequências poéticas de João Maimona ganham representações plásticas do artista Francisco Van-Dúnem. Por um caminho inverso ao que acontece na maioria das intersecções entre escrita e pintura, o que sucede, nas páginas desta coletânea, é uma produção pictórica que surge a partir da leitura que Van-Dúnem faz dos poemas de Maimona. Normalmente são os escritores que se inspiram em telas e/ou composições de artistas plásticos para delas fazer motivo de seus poemas, contos, romances, etc. A experiência feita por Van-Dúnem com os poemas de Maimona vem ainda pôr em xeque outra questão: a inteligibilidade dos textos do artista da palavra². Quando se propõe a transpô-los para as telas, o artista plástico automaticamente nos demonstra que há uma via de compreensão 
possível e palpável para as palavras do poeta, sempre tão estigmatizado por promover um hermetismo quase inalcançável. Porém, o fato de se expressar através de símbolos, de construir imagens aparentemente desconexas, quase surrealistas, faz com que suas intenções estéticas dialoguem diretamente com o signo da arte, sem perder a dimensão crítica do olhar.

Lugar e origem da belezatorna-se, portanto, um local de enlevo da palavra como portadora de uma plasticidade extrema ou como condutora de um discurso artístico que pode consolidar tanto pela escrita como pela visualidade da tela. O próprio João Maimona faz questão de deixar rastros do que pretende nesse livro logo na dedicatória: "À minha adolescência, maravilhosa fonte de inspiração para a compreensão do presente e construção do futuro, ofereço este vasto mosaico de imagens." (MAIMONA, 2003, p. 14, grifo nosso). A dedicatória é ainda complementada por uma nota do autor, logo na página seguinte, que diz:

Fidelidade gramatical oblige, procurei revisitar a minha obra poética. Na pequena história da arte moderna que ofereci à sociedade, descobri uma odisséia textual. Redescobri os rios e as árvores-paisagem que sugerem uma esperança crescente. Redescobri também a presença do véu. A greve e repouso dos navios. E veio o sentido da musicalidade. A multiplicidade de exemplos de adjectivação, patentes na minha obra, reafirmava o meu desejo de concretização de um projecto com função gramatical: homenagear, em percursos da expressão sugestiva da metáfora, da metonímia e do símbolo, um magnífico tempo verbal: o pretérito imperfeito do indicativo. E decidi oferecer à sociedade, por escrito e em universos poéticos, este Lugar e Origem da Beleza. (MAIMONA, 2003, p. 15)

Notamos logo que, entre dedicar o livro à sua adolescência e homenagear, através de suas principais articulações poéticas, o pretérito imperfeito do indicativo, há um paralelo muito significativo. Ainda mais se olharmos com calma para as indicações que Maimona deixa na "dedicatória" e que retornam na "Nota". Em primeiro lugar, ele diz que sua adolescência é fundamental para sua "compreensão do presente e construção do futuro". Com isso, tal época da vida fica em aberto, sempre viva na consciência do poeta e capaz de transformar seus caminhos tanto na vida quanto na escrita. Daí a homenagem ao pretérito imperfeito, forma contínua de um passado que expressa uma ação não concluída em si mesma. Outro ponto de encontro dos dois textos reside no "mosaico de imagens" citado na dedicatória. No segundo momento, ele é reconvocado através do "percurso da metáfora, da metonímia e do símbolo". Assim, fica nítida a intenção de Maimona de alertar seus leitores para a proposta do livro: unificar palavra e imagem, de tal forma que não haja ação temporal que as limite.

Ainda nesse caminho, o registro de um discurso muitas vezes transcende a época em que é escrito e permanece na atualidade de suas ideias e de suas expressões. Porém, o discurso poético ultrapassa essa 
premissa. Se a escrita é uma maneira de o homem inscrever-se no tempo, a poesia é uma forma de também se inserir no espaço. O poema é mais do que as palavras que o constituem. Há toda uma lógica na disposição dos versos, nos recuos e na localização do texto na página. Segundo Agnaldo José Gonçalves,

muitas vezes, o espaço entre os signos ou a distribuição do signo no espaço do poema é responsável por efeitos de sentido que jamais seriam conseguidos se nos mantivéssemos apenas na esfera da temporalidade. Até mesmo essa temporalidade é muitas vezes enriquecida, é expandida na esfera do poema, graças aos procedimentos de teor espacial dos elementos constitutivos do texto. (GONÇALVES, 2004, p. 31)

Portanto, não seria nenhum exagero se comparássemos o poema a um quadro; a folha em branco à tela; as palavras aos traços; os verbos às cores. Surge, por consequência, a possibilidade de se colocar em diálogo letras e telas, como tão bem propõe a ensaísta Carmen Tindó Secco, em vários de seus textos. Remetemos, por exemplo, à "Letras e telas moçambicanas em diálogo..." (SECCO, 2003, p. 254-261). Assim, a relação entre espaço e tempo na constituição da paisagem do poema, o sujeito poético como uma espécie de pintor das palavras e o processo de construção de uma linguagem artístico-verbal quase pictórica - tudo isso faz com que Lugar e Origem da Beleza evidencie os principais pontos do universo poético de João Maimona, acentuando e reiterando os locais de força de sua escrita e a busca por uma palavra poética recriadora:

\author{
entre fronteiras substanciais \\ escondi numerosas sonoridades \\ eram letras da semântica \\ renovável. fragmentos \\ entre fissuras transfiguradas. \\ (MAIMONA, 2007, p.34)
}

O encontro entre escrita e pintura ressalta a "semântica renovável" proposta por Maimona durante todo o seu percurso poético. A ideia de ter as palavras como um instrumento de transformação da paisagem, da voz e dos sentidos do texto é reiterada para instaurar, neste livro, o "lugar e a origem da beleza". Ao reler plasticamente o "mundo poético" de Maimona, Van-Dúnem nos mostra como as imagens criadas pelo poeta funcionam visualmente. Procedimento reiterado pelo próprio poeta quando este, em entrevista, afirma:

O que impressiona em Lugar e origem da belezaé o caminho do acasalamento entre a densidade da palavra poética e o belíssimo ritual de imagens. O mais extraordinário é a riqueza que resulta dessa simbiose. É uma espécie de universidade de todos os caminhos: o saber, as cores, os sinais de sedução, o mistério da natureza feminina, a sumptuosidade da gestão do domínio masculino, a salvação da beleza que cada um de nós concebe e fortalece no seu dia-a-dia. (MAIMONA, 2007, p. 97) 
Dessa forma, ler os poemas do livro de 2003, intercalando-os com os "ideogramas" do pintor, faz com que nosso percurso pelo "caminho" de João Maimona chegue ao ponto desejado, pois tal "simbiose" acaba reunindo os aspectos que investigamos na obra do autor e, de certa maneira, adensa alguns desses aspectos, demonstrando a força que têm no decorrer de seu processo de criação. Van-Dúnem, então, vai tentar reproduzir em seus "ideogramas"3 as imagens criadas por Maimona em seus versos. Não se tratando de uma tarefa simples, pois, como vimos com Octavio Paz, a imagem só pode ser interpretada e/ou pensada a partir dela mesma, Van-Dúnem vai aproveitar alguns detalhes reincidentes nos poemas de Maimona para construir a paisagem de suas telas, tentando, assim, através de um jogo de cores, traços e pequenos mosaicos, estabelecer o seu lugar de beleza. É o que vemos, por exemplo, nas duas primeiras telas do artista plástico que aparecem no livro do poeta. As telas, de título "Ave em vôo, I" e "Ave em vôo, II", representam interessante sequência de uma das imagens mais recorrentes na obra de Maimona: a da ave. Nos dois ideogramas encontramos aves alçando vôo, mas o que nos parece realmente relevante são os desdobramentos que as imagens da ave provocam na tela. Vejamos:

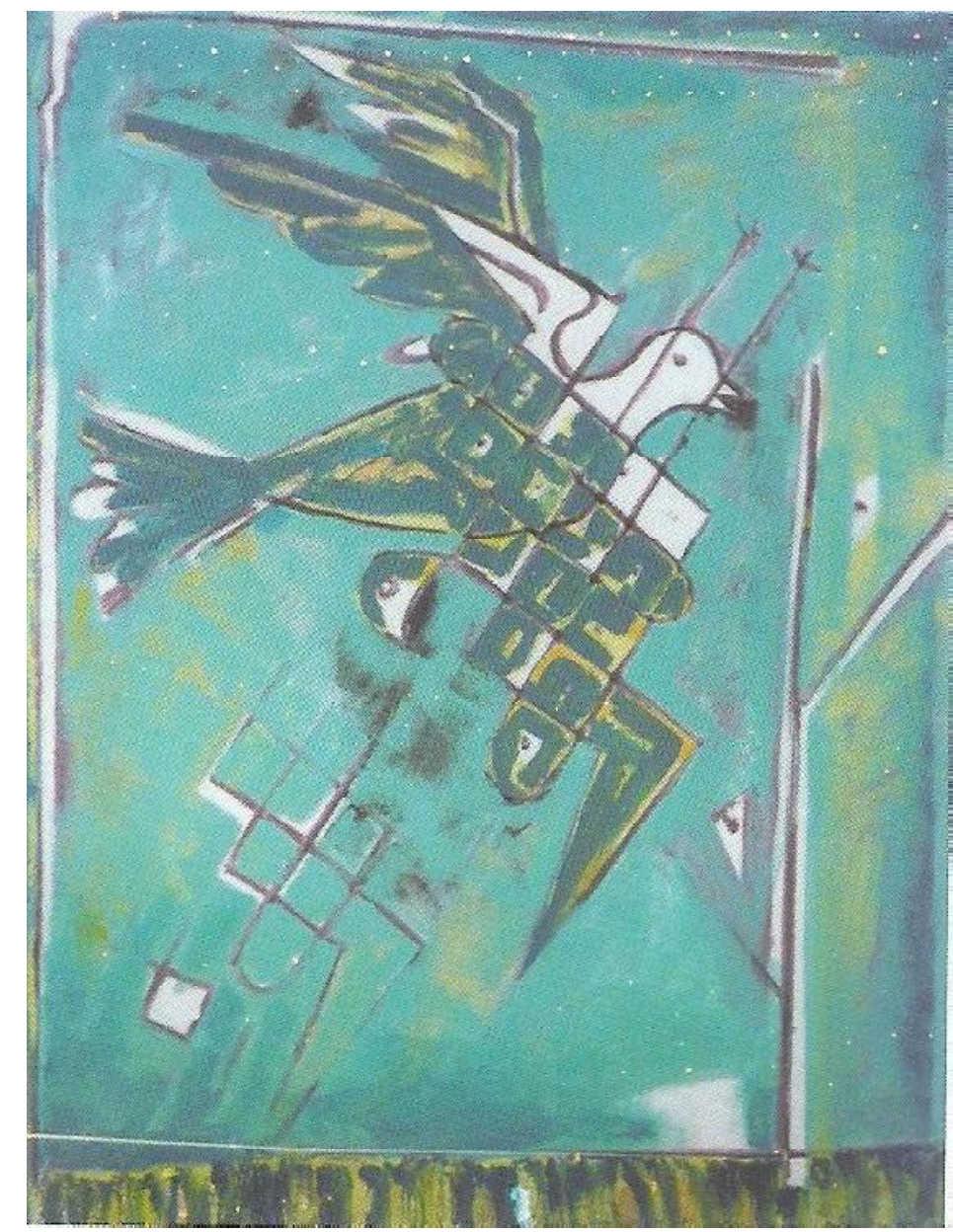

Ave em voo I 


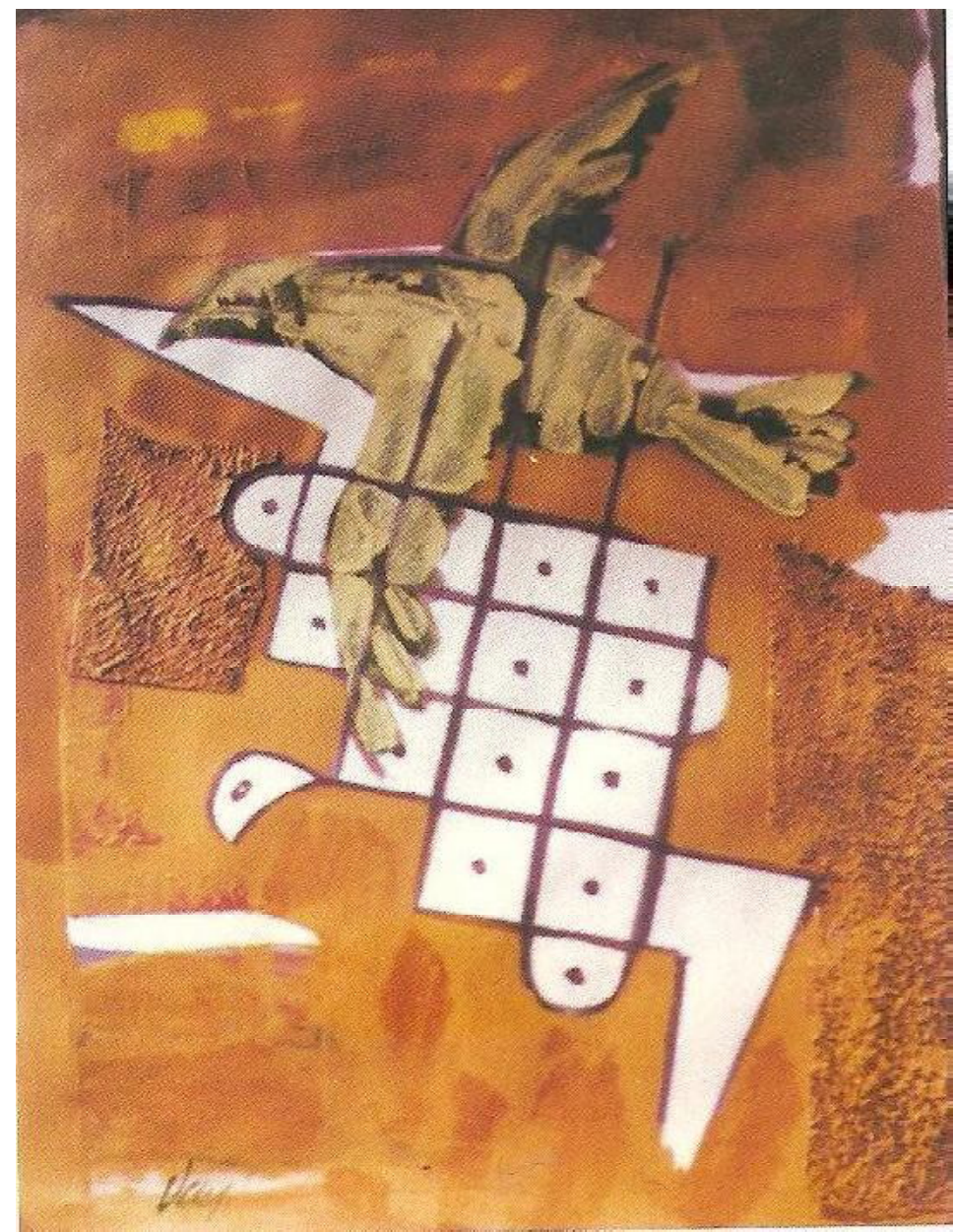

Ave em voo II

Fica fácil perceber que as aves se desdobram em pequenos mosaicos que remontam ao voo inicial, porém apontando para outra direção. Não custa lembrar, ainda, que uma das ferramentas mais férteis para a produção textual de imagens é a escrita em forma de mosaico, tão apreciada e tão bem realizada por João Maimona. Com isso, Van-Dúnem reproduz uma das mais marcantes características do poeta, abrindo vários possíveis caminhos de interpretação para a leitura de seus poemas. Nesse momento, encontramos o poema "A palavra e seu vôo", situado pouco depois da segunda tela:

a pureza do vôo: a humidade da conversa e o ruído inhabituel da escuridão.

as cartas que a noite reunia não possuíam invólucro. interrogações mudas e o desdobramento da memória. a fadiga do barco apenas obedecia ao dia e seus tijolos. a emoção procurava a palpitação da escrita. o paraíso útil, a desenhada frase e o dilacerado horizonte esclarecem a magra fertilidade da conversa.

ao longo da lírica cadeia contemplativa não havia percepções para a escuridão. 
e instantes para a fissura da escrita.

janela milenária.

o horizonte da escrita preocupava-se

em incorporar na doçura da medalha

fraccionada a emoção da inarticulação

de interrogações mudas.

inclinadas células. o declínio da amostra

figurada. contra a ruptura do limiar da

metamorfose estava a plenitude do

equinócio oferecendo a transparência

da memória. a indiferente substância

das músicas na excessiva dilatação

da lucidez e silenciosa arquitectura:

e a língua activa limitava-se

a brilhar entre expressões atrofiadas.

(MAIMONA, 2003, p. 42-43)

O voo da palavra proposto no título é um subentendido instante dentro do poema. Na verdade, Maimona nos mostra que a palavra é levada a alçar tal voo graças às articulações que o poeta utiliza para ressignificála. Assim, regressam, para a paisagem do poema, o barco fatigado, o horizonte, as ideias de fissura e fratura, as interrogações e a memória. $\mathrm{O}$ poeta projeta o voo da palavra, articulando imagens que dialogam no espaço da "humidade da conversa" e que se agrupam para a reconstrução de significados dentro de uma "língua activa" na busca por superar as expressões atrofiadas. São os dois dísticos, que respectivamente abrem e fecham o poema, os responsáveis por tal entendimento, pois funcionam como uma moldura para as outras estrofes que se constroem através de uma "conversa" de imagens, pela atividade da língua. Tendo, portanto, os dísticos como moldura, o poeta exercita sua capacidade de formar os mosaicos na escrita dos versos. Os fragmentos textuais e as imagens se formam e se organizam graças à conjugação metafórica e à pontuação que o poeta estabelece dentro do texto. Vale ressaltar, ainda, a disposição do poema nas páginas do livro, já que o espaço entre as estrofes é um pouco maior que o tradicional. Dessa maneira, "A palavra e seu vôo" é uma tela poética na qual os elementos formadores da poética deste angolano impulsionam o voo da palavra.

A memória parece-nos receber um importante papel neste poema. Não só pela aparição textual do vocábulo, mas pela forma como o produtor angolano em questão gmonta has imagens do texto. A ideia fluida de desdobramentos involuntários que uma imagem suscita à outra, nos faz pensar que é a memória o principal norteador da disposição e ordenação do poema. Logo na segunda estrofe, vemos sua primeira aparição: "interrogações mudas e o/ desmembramento da memória". Desmembrar a memória é dissolver a noção de um corpo único, fechado e não ativo. Com isso, João Maimona diz a seus leitores que fala de uma memória suscetível aos momentos, às ações e aos pensamentos que ele, poeta, pode e quer representar em seus versos. Vemos isso, com clareza, na sequência do poema, pois é através deste desmembramento que 
retornam, por exemplo, "a fadiga do barco", "a palpitação da escrita" e "o dilacerado horizonte". A memória vai, assim, auxiliando o poeta na formação da paisagem do poema. Silvina Rodrigues Lopes, em seu ensaio "Poesia, memória excessiva", nos fala sobre esta questão:

Pensar o poema como memória que não se extingue, justamente porque é memória enquanto operação, isto é, memória activa, forma dinâmica e não mecanismo, implica considerar nele a dimensão da leitura como constitutiva. Quer dizer, admitir que os seus limites, finitos, encerram um potencial infinito de memória, e não apenas um conjunto de recordações que o seu autor nele colocou. Como núcleos poéticos, as imagens funcionam como recordações que se transcendem, que abrem corredores para as emoções (...) (LOPES, 2003, p. 74)

Dessa forma, o poema e suas memórias são capazes de despertar - através das imagens que produz - emoções, sentimentos, sensações. Os leitores observam e contemplam seu mosaico, identificando-se com ele ou questionando-se sobre sua constituição. É tal essência que VanDúnem tenta capturar em seus ideogramas:

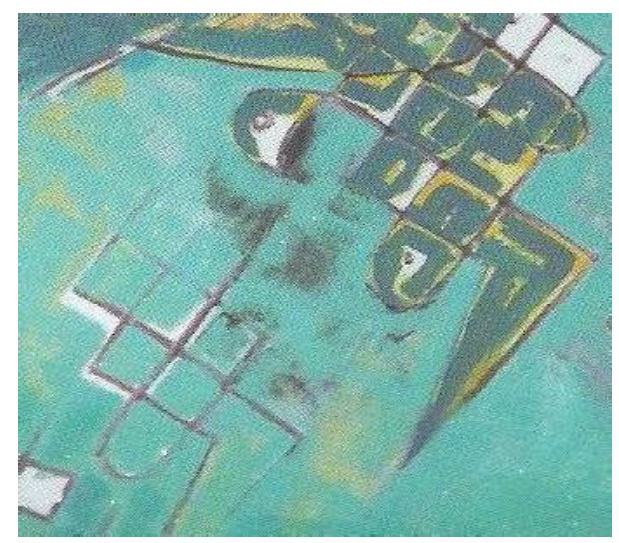

Nesse pequeno recorte que fazemos do ideograma I é possível notar os detalhes da ave que se desdobra da figura principal da tela. Notamos, então, uma estrutura fragmentada, em que pequenas figuras geométricas formam uma nova ave em mosaico. Os pequenos estilhaços variam em tons de verde e repensam a imagem da ave, modificando a direção de seu voo inicial e suscitando, ainda, uma nova formação fragmentada mais abaixo, já deslocada da anterior. O desmembramento da imagem principal e sua fragmentação em novas proposições imagéticas nos fazem lembrar os versos do poema em questão:

inclinadas células. o declínio da amostra

figurada. contra a ruptura do limiar da metamorfose estava a plenitude do equinócio oferecendo a transparência da memória. a indiferente substância das músicas na excessiva dilatação da lucidez e silenciosa arquitectura: (MAIMONA, 2007, p. 43) 
A "silenciosa arquitectura" é desenhada no poema, através do "declínio da amostra figurada". Assim, as transformações semânticas e na paisagem do poema acontecem graças às rupturas do processo criativo, que se pretende representação de uma realidade estilhaçada, como vimos anteriormente. A memória, neste momento do texto, oferece sua transparência e o faz para se integrar ao discurso poético. Convocamos novamente a voz de Silvana Rodrigues Lopes: "porque o que há de memória na recordação é um vazio: a força do acontecimento, que, não sendo senão força, sensações sem conceitos, busca desde logo a que ligar-se, um abrigo para seu vazio, a linguagem". (LOPES, 2003, p. 62).

Ao se integrar à linguagem e se propor como parte formadora do poema, a memória se estabelece como parte do processo de criação e não como fim deste mesmo processo. Por isso, vemos Maimona convocáa como "desmembrada" e "transparente", adjetivos que pressupõem um referente "inacabado", constante produtor de sentidos. Van-Dúnem, então, ao representar os desdobramentos da ave em seu voo, reinventa os mosaicos produzidos por Maimona, jogando com as tonalidades de uma mesma cor e, consecutivamente, com os estágios de ressignificação propostos pelo poeta em seu trabalho com a linguagem.

Seguindo as páginas de Lugar e origem da beleza, percebemos que o extremo trabalho com a linguagem, citado pelo próprio autor, faz com que este livro seja um grande quadro de seu "mundo poético". A proposta de recolher seus principais lugares de força e relacioná-los à pintura faz da escrita um espaço de transição entre o possível e o desejado, entre a imagem e a letra, entre a beleza e suas origens. É o que podemos observar nos três poemas que antecedem o sexto "Ideograma" de Van-Dúnem. $O$ primeiro deles é o poema "Seqüência":

\section{a pequena máscara envolve a cidade. calçadas surdas. canções divididas e o rosto do meio-dia afixam pálidas na última mão da multidão a crueldade das águas. era deste rio que vinha a nova madrugada.}

(MAIMONA, 2003, p. 68)

A máscara que, no poema, "envolve a cidade" é o elemento escolhido por Van-Dúnem como centro do "Ideograma". A ideia inerente de encobrimento que a "máscara" supõe, conduz o poema, já que é a partir dela que o sujeito poético nos revela "calçadas surdas", "canções divididas" e a "crueldade das águas". A representação do espaço da cidade na paisagem do poema ressalta o desequilíbrio entre os elementos e as imagens que formam. Assim, as "calçadas são surdas". Logo, não podem ouvir as "canções divididas", da mesma forma que a "máscara", além da cidade, encobre também o "rosto do meio-dia". Já as "águas cruéis" são as mesmas que formam o rio anunciador de uma "nova madrugada". Ou seja, a ação ou imagem anterior "encobre" o sentido da seguinte e viceversa. O poeta consegue, então, estabelecer uma "sequência" - como proposto no título -, utilizando imagens que interagem e, mais que isso, se chocam no decorrer do texto. Vejamos então o recorte da 


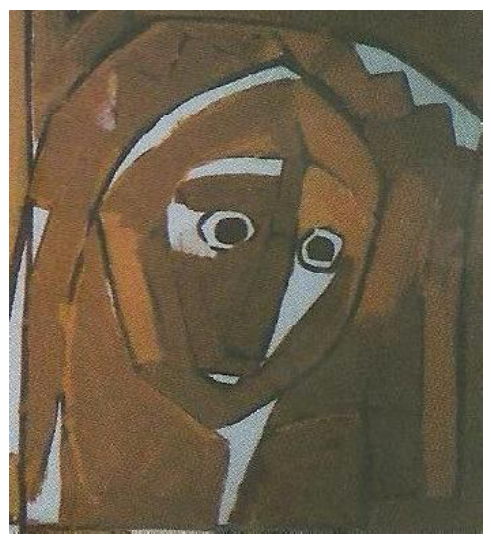

Como observamos, para Van-Dúnem, máscara e rosto se confundem, ressaltando a interação dos dois elementos na formação da paisagem do texto e da tela. Além disso, notamos, nas partes brancas da imagem, a preocupação do artista em demonstrar a expressão de sofrimento e assombro, principalmente através do olhar em direção ao vazio. 0 segundo poema, "Água de hipocrisia" nos diz:

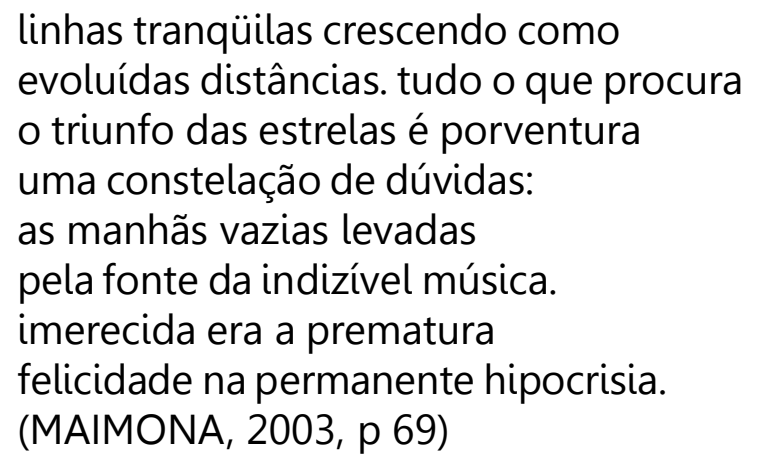

As imagens se vão adensando de acordo com o crescimento das "linhas tranqüilas". Aqui, o poeta questiona a relação entre sonho e dúvida, logo entre, realidade e imaginação. As relações deste poema com o anterior são manifestas. Podemos citar, por exemplo, a percepção temporal da "nova madrugada" que se transforma aqui em "manhãs vazias". Nas "canções divididas" que agora se transfiguram na "fonte da indizível música". Ou, ainda, na "crueldade das águas" que, neste momento, intitulam o poema de "Água de hipocrisia". Se, em "Seqüência", as imagens provocam um jogo de sentidos entre si, no poema da página 69 elas evoluem de acordo com o crescimento das linhas e se distanciam de possíveis e/ou concretas definições. Por isso, a música é indizível, as manhãs vazias e a felicidade prematura. Novamente, trazemos a leitura de Van-Dúnem, em novo recorte do sexto "Ideograma":

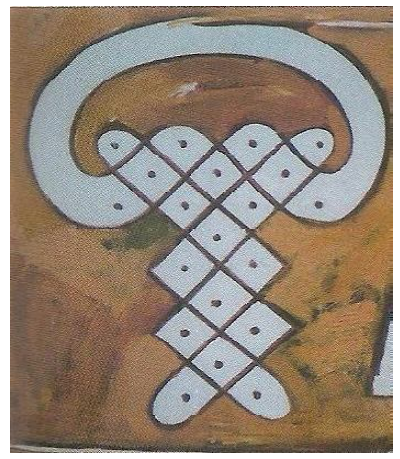


As "linhas tranqüilas" de Maimona se entrelaçam na proposta de Van-Dúnem, e vão crescendo interligadas. Novamente a cor branca é escolhida pelo artista para contrastar com o fundo da tela. Mas se, no recorte anterior, entendemos que tal cor enfatiza a expressão extenuada da máscara/rosto, aqui pensamos em sua utilização como sinal da harmonia com que as linhas se encontram e que, mesmo em um ambiente de hipocrisia representado pelo tom escuro do fundo da tela, são capazes de criar novos caminhos. É hora de vermos, então, o terceiro poema da sequência, "Segunda noite":

que silêncio requintado desenhado à mão livre em absoluta linha de terra teria convergido para a noite auxiliar? ou estaria a tornar-se impróprio para a absorção virtual? de entre as linhas da terra pressentia-se a matéria infinita. enorme instante cintilante: engendrava as muralhas da segunda noite. (MAIMONA, 2003, p. 70)

Notemos que o que fora madrugada, e se transformara em manhã, agora é noite, da mesma maneira como as "canções surdas" que viraram uma "indizível música", agora são "silêncio requintado". Já a relação da água, existente nos poemas anteriormente analisados, se desloca, neste momento, para a imagem da terra como "uma absoluta linha" de onde é possível pressentir a "matéria do infinito". A paráfrase nos parece necessária para, a partir dela, convocar, agora sim, a tela completa de Van-Dúnem:

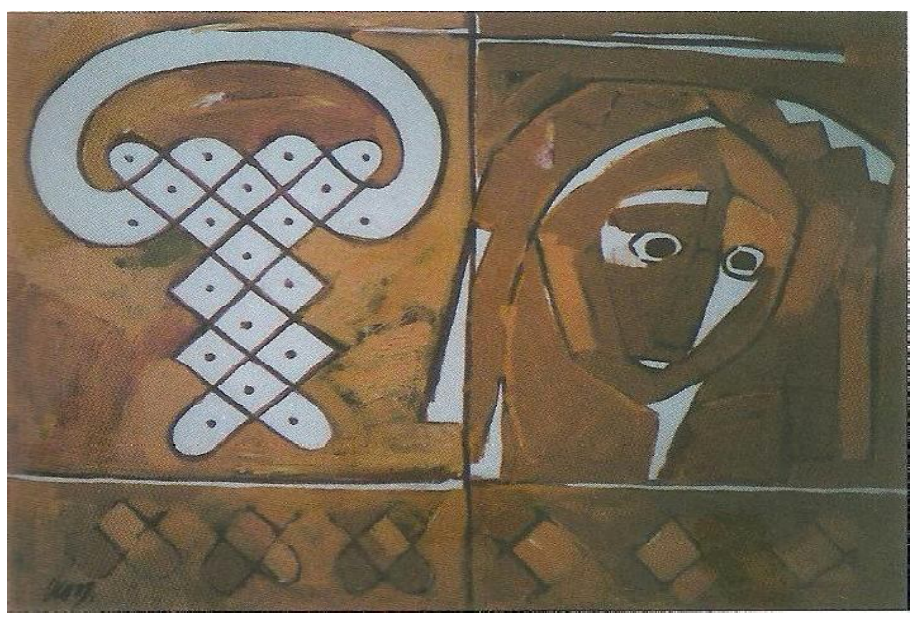

A infinitude que a terra traz para a paisagem do poema nos remete à escolha dos tons escuros, majoritariamente os marrons, que o artista plástico utiliza em quase toda a pintura. Notemos que a mistura de tonalidades de marrom gera uma cor muito próxima à da terra e que ela se infiltra até mesmo nas figuras da tela:

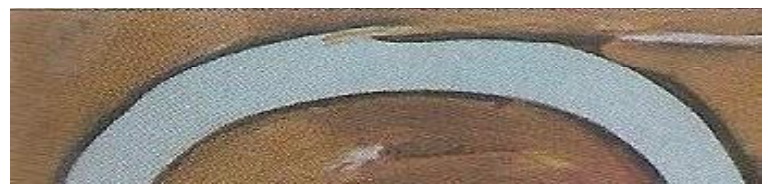


Aparentemente fechada, a figura que fica ao lado da máscara apresenta um rompimento, tornando, para usar as palavras do próprio poeta em outro momento, "penetrável o discurso". A ideia persiste se percebermos que o branco da imagem entra em contato com o resto do quadro e se espraia para o outro lado da tela, rompendo até a divisória feita por Van-Dúnem:

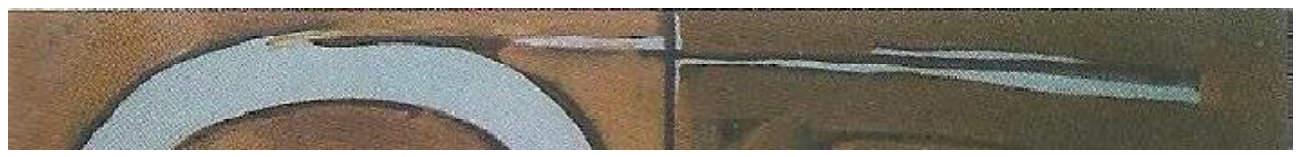

Cremos que, com esses artifícios, o pintor consegue mergulhar no universo do poeta e estabelece, nessa tela, a relação que há entre os três poemas aqui analisados. Aliás, a proposta de ambos de promover este encontro entre poesia e pintura, demonstra como os caminhos que tentamos percorrer no decorrer deste são válidos e se configuram em terreno fértil para outras muitas análises.

São, ao todo, onze os "Ideogramas" de Van-Dúnem que permeiam e dialogam com a escrita poética de João Maimona neste Lugar e origem da beleza. Todos estabelecem relação com um ou mais poemas da coletânea, porém nossa intenção era apenas demonstrar como acontece e se desenvolve tal interação entre a palavra poética de João Maimona e as telas, traços e cores de Francisco Van-Dúnem. Acreditamos que a relação interartes, promovida pelos dois artistas neste livro, é uma maneira de o poeta reiterar os percursos de seu "caminho", ora "doloroso das coisas", ora "berço de palavras renováveis": uma pintura de letras na folha.

\section{REFERÊNCIAS BIBLIOGRÁFICAS}

GONÇALVES, Agnaldo José. O museu movente, o signo da arte em Marcel Proust. São Paulo: UNESP, 2004.

LOPES, Silvina Rodrigues. Literatura, defesa do atrito. Porto: edições vendaval, 2003.

MAIMONA, João. Lugare origem da Beleza. Luanda: Kilombelombe, 2003.

PAZ, Octavio. O arco e a lira. Trad. Olga Savary. Rio de Janeiro: Nova Fronteira, 1982.

RICOUER, Paul. gO processo metafórico como cognição, imaginação e sentimento h. Tradução: Franciscus W. A. M. van de Wiel. In: SACKS, Sheldon (org). Da metáfora. São Paulo: Educ / Pontes, 1992.

ROSA, João Guimarães. Manuelzão e Miguilim. Rio de janeiro: Nova fronteira, 2001.

SECCO, Carmen Lúcia Tindó. Letras e telas moçambicanas em diálogo. In . _. A magia das letras africanas. Ensaios escolhidos sobre as literaturas de Angola e Moçambique e alguns outros dialogos. Rio de janeiro: ABE Graph Editora / Barroso Produções Editoriais, 2003, p. 254-261. 


\section{NOTAS}

1. Trata-se de Memórias sentimentais de João Miramare Serafim Ponte Grande.

2. Lembramos, aqui, que a pesquisadora Carmen Lúcia Tindó Ribeiro Secco apresentou, no Il Fórum de Angolanistas em comunicação intitulada "Travessias aladas: Diálogos entre literatura e artes plásticas de Angola", uma análise da interlocução entre a poesia de João Maimona e os quadros de Van-Dúnem. Não tivemos acesso a esse texto, mas devemos aqui registrá-lo.

3. O artista plástico intitula as telas que permeiam as páginas de Lugar e origem da beleza (2003) dessa maneira. Para nós a titulação não é nem um pouco ingênua, já que une mais uma vez a palavra à imagem, ressaltando os aspectos comuns entre os dois e intensificando a proposta de seu trabalho neste livro de Maimona. Vale ainda lembrar que a titulação completa das telas se dá como "Ideograma x realismo", o que reforça nossa ideia. 